\title{
“LOCE LOCE METÁ RÊ-LÊ!?”: posições de gênero-erotismo entre homens com práticas homossexuais adeptos do candomblé do Recife
}

"LOCE LOCE METÁ RÊ-LÊ!": positions of gender-eroticism between men whit homosexual practices in Candomblé of Recife

"LOCE LOCE METÁ RÊ-LÊ!": posiciones de género-erotismo entre hombres con prácticas homosexuales miembros del Candomblé de Recife

\section{Luis Felipe Rios}

Universidade federal de Pernambuco, Recife, PE, Brasil

\begin{abstract}
Resumo
O artigo discute o modo como desejos eróticos, práticas sexuais e atributos de gênero são situados na cultura sexual do Candomblé de Recife e operados nas narrativas de seus integrantes homens que fazem sexo com homens. Os dados foram coletados como parte de uma pesquisa etnográfica guiada por uma perspectiva teórica que entende a sexualidade como sócioculturalmente construída. Num contexto onde os homens estão estabelecendo interações sexuais que nem sempre estão de acordo com os ideais hegemônicos de oposição entre atividade e passividade, masculinidade e feminilidade, se configura uma cultura sexual onde articulações entre gênero, sexualidade e erotismo, dissidentes da heteronorma, são avaliadas positivamente.
\end{abstract}

Palavras-chave: Candomblé, Homossexualidade, Homens, Gênero, Erotismo.

\begin{abstract}
The article discusses how erotic desires, sexual practices and gender attributes are situated by sexual culture Candomblé of Recife, and operated in the narratives of adepts men who have sex with men. Data were collected as part of an ethnographic research, guided by a theoretical perspective that understands sexuality as socially and culturally constructed. In a context where men are establishing sexual interactions that do not always agree with the hegemonic opposition between activity and passivity, masculinity and femininity, there is a sexual culture in which the connections between gender, sexuality and eroticism, dissidents of heteronorm, are positively evaluated.
\end{abstract}

Key words: Afro-Brazilian religions, homosexuality, men, gender, erotism. 


\section{Resumen}

El artículo discute cómo los deseos eróticos, las prácticas sexuales y los atributos de género están ubicados en la cultura sexual del Candomblé de Recife y la forma en que son operados en los relatos de sus miembros, hombres que tienen sexo con hombres. Los datos fueron recogidos como parte de una investigación etnográfica guiada por una perspectiva teórica que entiende la sexualidad como construida social y culturalmente. En un contexto donde los hombres están estableciendo interacciones sexuales que no siempre se ajustan a los ideales hegemónicos de oposición entre masculinidad/actividad y feminidad/pasividad, hay una cultura donde conexiones entre género, sexualidad y erotismo, disidentes de la heteronorm, son evaluadas positivamente.

Palabras clave: Candomblé, homosexualidad, hombres, género, erotismo.

\section{Introdução}

Este artigo analisa o modo como desejos eróticos, práticas sexuais e atributos de gênero são situados pela cultura sexual de terreiros de candomblé do Recife, e operados nas narrativas de seus integrantes homens que fazem sexo com homens.

A literatura tem consagrado o xangô como a modalidade de religião afrobrasileira em Pernambuco (Ribeiro, 1952; Motta, 1991). No entanto, desde a década de 1960, o candomblé, na literatura especializada identificado à Bahia, também aparece em Pernambuco, tendo sido introduzido na Região Metropolitana do Recife por ex-pais de santo do xangô, re-iniciados no modelo baiano de culto aos orixás na Baixada Fluminense, estado do Rio de Janeiro (Rios, 2000).
Como em Pernambuco o termo candomblé tornou-se categoria ampla para designar as religiões afro-brasileiras africanistas ${ }^{1}$, os religiosos usam o termo candomblé de nação para falar dos terreiros que seguem o modelo baiano. Para falar do xangô, o termo utilizado é nagô. Assim, na atualidade, junto com o nagô, a umbanda e a jurema, o candomblé de nação constitui o quadro do que se pode chamar de campo religioso afro-pernambucano (Rios, 2000; Brandão \& Rios, 2002).

É importante já de início destacar que há importantes distinções nos modos como o xangô e o candomblé de nação lidam com as posições de sexualidade e de gênero dos adeptos. Se é verdade que nas religiões afro-brasileiras africanistas há maior abertura às sexualidades dissidentes da heteronorma (Landes, 1967; Fry, 1982; Teixeira, 1987; Segato, 1995; Birman, 1995; Rios, 2004), também o é que no 
xangô tradicional os homens homossexuais efeminados são estigmatizados e discriminados. Fato que não ocorre no candomblé de nação, que se apresenta aberto para as homossexualidades expressas por homens a partir daquilo que socialmente é concebido como feminino.

Essa divisão no campo afrobrasileiro, que distingue os terreiros que aceitam e mesmo incentivam o uso de atributos socialmente classificados como femininos pelos homens, dos terreiros que restringe a expressão e status na hierarquia religiosa dos homossexuais efeminados, não é exclusiva do Recife (cf. Landes, 1964). Já abordei aspectos que sustentam o estigma e a discriminação em relação aos homens efeminados nos terreiros do Rio de Janeiro (Rios, 2002a, 2004 e no prelo), desta feita quero me ocupar dos aspectos do sistema simbólico e das práticas sociais que possibilitam uma sociabilidade religiosa não apenas homófila, mas também aberta para as transgenerações, no candomblé de nação do Recife.

Embora não me proponha a aprofundar os aspectos históricos que concorrem para essa organização do campo afroreligioso, a partir das marcações de gênero, sugiro que a abertura do candomblé de nação aos homens efeminados se deveu, entre outros fatores, ao fato de que foram homens com práticas homossexuais, discriminados pelos sacerdotes e sacerdotisas do xangô, que buscaram, no Sudeste, pelo candomblé (Rios, 2000). Nesse contexto, parece-me que a midiatização da figura do pai de santo Joãozinho da Goméia foi de suma importância para configurar fluxos migratórios religiosos e a chegada no Recife de um candomblé aberto às agencias femininas pelos homens. Joãozinho foi um importante pai de santo baiano, radicado no Rio de Janeiro em 1947. Vinte anos depois, ele ganhou a capa de uma das mais importantes revistas da época, O Cruzeiro (Lody \& Silva, 2002). Um elemento importante na imagem pública de Joãozinho e de seu candomblé era o fato de ele alisar o cabelo; permitir o uso de indumentária feminilizante entre os homens, seus filhos de santo; e vestir os orixás, em homens, com saia. Isso fazia com que fosse percebido por muitos estudiosos e adeptos como desvirtuando o candomblé (cf. Landes, 1967). De certa forma, e ainda que nem sempre referenciados como descendentes da Goméia, é o modelo estético de candomblé de Joãozinho que chega ao Recife: um candomblé onde os homens "efeminados" ganham status impossível de ser alcançado no xangô tradicional.

Apoiado em teorias pósestruturalistas da sexualidade e do gênero (Vance, 1989 e 1995; Rubin, 1993 e 1998; Weeks, 1985; Parker, 1991; Stolcke, 2004) neste trabalho argumento que no candomblé de nação vigora uma categorização de 
gênero que rompe com dicotomia masculino/feminino, hegemônica na sociedade englobante. Em um contexto onde homens estão estabelecendo interações sexuais que nem sempre obedecem ao ideal de oposição entre atividade-masculinidade e passividade-feminilidade, configura-se uma cultura sexual pautada numa lógica das hibridizações e onde articulações entre gênero, sexualidade e erotismo, dissidentes da heteronorma, são valorizadas na medida em que são mais pertinentes para orientar a vida sexual dos atores.

Este texto está organizado de modo que, após situar os enquadres metodológi$\cos$ da pesquisa que originaram os dados aqui discutidos, passo à apresentação dos resultados, em três tempos. Inicialmente abordo o panteão mítico do candomblé de nação e como este situa as categorias de gênero. Em seguida mostro como as categorias de gênero são utilizadas para situar a construção da subjetividade dos adeptos. Por fim, apresento uma categorização de homens que se organiza no diálogo entre a classificação mítica de gênero e o modelo passivo/ativo das classes populares. Nas discussões argumento que o rompimento da dualidade através da categoria nativa loce possibilita instrumental mais potente para que os homens guiem interações que incorporam modalidades de experiências eróticas que se afastam da rígida oposição informada pelo par masculino/feminino, que prepondera na orientação das interações sexuais na cultura popular da sociedade englobante (Parker, 1991).

\section{Método}

Os dados aqui analisados foram coletados no Recife, no âmbito de uma pesquisa etnográfica, realizada entre 1995 e 1997, junto a terreiros de candomblé de nação (Rios, 1997). Esta se desenvolveu através de observações sistemáticas em quatro terreiros desta ultima denominação, e um terreiro nagô considerado como um dos mais tradicionais da cidade. Além desses quatro terreiros, participei de reuniões, festas e rituais em vários outros centros de culto afro-brasileiros no Grande Recife. Também entrevistei 10 homens e $10 \mathrm{mu}-$ lheres integrantes de religiões afrobrasileiras. Oito dos homens se declararam homossexuais e integravam casas de candomblé de nação. As entrevistas versaram sobre a inserção dos homens com práticas no campo religioso afro-brasileiro, e em especial no candomblé. Na apresentação dos relatos, utilizo de nomes fictícios para garantir o anonimato dos meus interlocutores. 


\section{Resultados}

\section{Gênero e as Relações entre os Deuses}

Logun Edé nasceu do adultério incestuoso entre Oxossi, o caçador, e Oxum, a rainha das águas doces. Ao nascer ele foi abandonado em um lago: sua mãe temia que o fato fosse descoberto por seu marido, Ogum, o terrível deus da guerra. Adotado por Oiá, a guerreira, o menino cresceu. Jovem, Logun Edé reencontrou o pai. Hábil nas técnicas da caça, Oxossi pediu que o menino usasse do arco e da flecha, mas o garoto não conseguiu acertar a caça. Zangado, o pai deu vinte e quatro horas para o garoto trazer-lhe uma presa. Atormentado, o garoto saiu pela floresta. Parando às margens de um regato, no fundo cristalino das águas, Logun viu um belo animal. Usou de suas novas armas e conseguiu acertar o animal. Mas, por compaixão, resolveu devolvê-lo às águas. Ainda no regato, Logun avistou Oxum a mirar-se em um espelho. Aborrecida com o atrevido garoto a espreitá-la, o enfeitiça sob a forma de um cavalo marinho. O menino assim metamorfoseado mergulhou nas águas. Preocupada com a ausência tão prolongada do jovem, Oiá saiu à procura de Logun. "Onde estaria ele? Será que descobrira a sua real maternidade?" Pensou. Oiá buscou, então, pela senhora das águas. Revelado o acontecido, o garoto foi desencantado. Um acordo foi feito desde então: seis meses moraria com o pai, na floresta, e seis meses moraria com a mãe, nas profundezas das águas; seis meses comeria caça e seis meses comeria peixe.
No contexto das religiões afrobrasileiras, narrativas como a apresentada acima são muito mais que simples alegorias. Por seu caráter sagrado elas têm o lugar de saber instituído, sendo, por isso, meio privilegiado para a veiculação das concepções do que as coisas são e como elas devem acontecer na ordem do mundo (Segato, 1995; Augras, 1983; Rios, 1997 e 2004). Por tudo isso, tomei o corpus míti$\mathrm{co}^{2}$ do orixá Logun Edé como ponto de partida para compreender o que o candomblé tem a dizer sobre os homens com práticas homossexuais.

Edé não gostava de estar nas terras de Oxossi. Este era bastante rude com o garoto, sobretudo quando ele apresentava maneirismos próprios às iabás. Assim, logo que tinha uma chance, ele se disfarçava de iabá e entrava no reino da sua mãe, onde só mulheres podiam estar. Freqüentemente ele era confundido com a própria Oxum. Certo dia, uma das mulheres do reino, encontrando-se com a rainha das águas doces, pôs em causa a sua identidade. Disse para ela que a verdadeira Oxum estava na mesa das iabás, onde estivera há poucos minutos. Oxum apressa-se para desmascarar a impostora. E qual não foi a sua surpresa: sob as vestes femininas encontrou o seu amado filho travestido. Contudo, as performances de Edé quase sempre se traíam. Ele não sabia lidar bem com atividades, com as tarefas domésticas, as tarefas e fazeres próprios das mulheres. 
Em outra ocasião, houve uma grande festa no mundo dos deuses e Logun Edé não tinha roupas adequadas para ir a tal evento. Quando Oxum saiu de casa, o menino tomou uma das muitas vestes da mãe e uma cora, tendo o rosto coberto por uma franja de canutilhos (filá). Chegando ao baile todos ficaram impressionados com a beleza da misteriosa jovem. O curioso Ifá, o orixá da adivinhação, resolveu descobrir a identidade "da moça" e levantou o filá. Envergonhado, Edé fugiu para a floresta. Seu pai, encantado com a beleza do filho, travestido de iabá, o segue e lá o possui sexualmente.

Os mitos até aqui elencados estão atravessados por uma categorização de gênero onde os deuses são classificados em aborós, iabás e metá-metás (ou, simplesmente, metá). Num primeiro plano analítico, pode-se dizer que os orixás aborós, como Ogum e Oxossi, e iabás, como Oxum e Oiá, atualizariam os atributos de gênero das categorias masculino e feminino da sociedade abrangente. Segato (1995) destaca a autonomia como o principal atributo dos deuses aborós, em contraposição à relativa dependência, em especial quando estão interagindo com os primeiros, que caracteriza as iabás.

O candomblé de nação apresenta, em adição, uma terceira categoria de gênero, o metá, que acrescenta uma novidade ao arcabouço comumente usado para organizar a vida social, considerando o referen- cial da sociedade abrangente. O que vai caracterizar os orixás metás, não é, como se poderia pensar, a homossexualidade. Os mitos contam que muitos deuses aborós ou iabás tiveram relações sexuais com orixás do mesmo sexo. Ser metá tem a ver com o fato de o deus hibridizar características, comumente classificadas em categorias sociais diferentes, dentre elas (mas não só) as de gênero. Assim, os metás transformam-se de, e/ou são a um só tempo, animal-humano (Logun e Oxumaré); vegetalhumano (Ossaim); pênis-vagina (Oxumaré); iabá-aboró (Logun e Oxumaré); fenômeno natural-animal (Oxumaré); peixemamífero (Logun) etc.

Contudo, em aparente antagonismo com a própria existência da categoria, há narrativas míticas onde os santos metás são perseguidos, rechaçados e discriminados.

Oxum, por não ter podido criar o seu filho, amaldiçoou as primeiras crianças que nasceram depois dele. Nanã estava grávida e deu a luz a três filhos "bizarros": Bessém (seis meses cobra, seis meses arco-íris, seis meses macho, seis meses fêmea), Ossaim (metade homem, metade folha) e Omolú (leproso). Vendo aquilo, Nanã se enfureceu; de algum modo se vingaria de Oxum. Além disso, Nanã percebeu que Ossaim não era chegado às mulheres. Por conta disso, ela ficou revoltada: passou a acreditar que todos os homens teriam a possibilidade de ter relações sexuais com outros homens. 
Passou a odiar a todos eles. Sabendo que Logun era filho de Oxum, ela passou a observá-lo. Percebeu que ele tinha um jeito muito delicado, que queria ajudar a todos, não tinha o jeito aboró de se comportar, ou seja, não era impulsivo, agressivo ou rude. Nanã então o amaldiçoou: passou a chamá-lo de $\operatorname{Logun}^{3}$, algo que seria o equivalente aos termos pejorativos usados para categorizar os homens que transam com outros homens, como veado, frango ou bicha. Nanã soltou vários feitiços sobre a família de Logun. Fez Oxossi se apaixonar por Ossaim só para provar que ele não era homem de verdade; colocou vários homens nos caminhos de Oxum para provar que ela não era uma mulher de confiança; jogou um feitiço sobre os olhos de Logun Edé para que ele enxergasse apenas os homens, depois inverteu o feitiço e ele passou a andar apenas com as mulheres. A questão é que, vivendo só com os homens, ele perdeu o interesse pelas mulheres. Gostava de estar com elas, vestir-se como elas, mas não as desejava sexualmente.

O que é preciso ser lembrado é que os mitos estão enraizados na realidade sócio-cultural abrangente, onde impera formações discursivas contrárias às "inversões" do comumente esperado para sexo/sexualidade/gênero, e que, junto com outros determinantes, também contribuem para as suas produções. Mitos como os últimos apresentados podem ser interpretados como um "sinal de alerta", informando que os metás, por contrariarem a ordenação concebida como "natural" são perseguidos/discriminados, em especial pelos representantes das normas, o pai (Oxossi) e as avós (Iemanjá e Nanã).

Quero sublinhar que o que chama mais atenção nos processos de estigmatização que afetam os seres metás é menos a orientação sexual e mais a sensação de "bizarrice" ou estranheza que as hibridizações por eles estabelecidas provocam nos outros, como me disse Mário (filho de Logun Edé, que me contou os mitos que relacionam os filhos de Nanã à maldição de Oxum). É só quando a articulação configura o ser como uma espécie de quimera ou ciborgue $^{4}$ (Haraway, 1994) que o orixá, de fato, ingressa na categoria metá-metá. Até porque a lógica da articulação dos atributos disponíveis é incorporada por todos os deuses, ainda que em graus variados.

Assim, seguindo a perspectiva de Segato (1995), dos orixás como subcategorias de gênero, pode-se identificar uma variedade de modelos de iabanidade (feminilidade) - de Oxum, a mais feminina, à Iansã, a mais masculina das iabás - e de aboronidade (masculinidade) - de Oxalá, o mais feminino, à Ogum, o mais masculino dos aborós. Acrescentando os orixás metás, que não foram tematizados por Segato (1995), temos também um leque de metanidades (híbridos de gênero), prefigurado nas figuras de Logun Edé (o menino afe- 
minado, brincante dos atributos de gênero), Oxumaré (o deus transexual, que de tempos em tempos troca de sexo e gênero) e Ossaim (o feiticeiro, homem-folha, homossexual masculinizado).

O candomblé parece ter sido mais sensível às diferenciações na construção das subjetividades, encaminhando o trabalho de configurar e re-configurar as categorias de um modo que possibilita um leque de subcategorias de gênero já bem mais próximo do real. Assim, temos as categorizações de gênero dessa religião se organizando como um arco-íris, cheio de modos de estar-no-mundo.

Em adição, as nuanças nas formas estéticas de ser se tornam ainda mais exuberantes e complexas na medida em que, dentro da gama de subcategorias/orixás de aboró, iabá e metá, há uma infinidade de variações, a depender das qualidades dos orixás. Cada orixá (por exemplo: Oxum) seria como uma categoria taxonômica que engloba um agrupamento de seres míticos (Karê, Ijimum, Opará, Ipondá, etc.) que se assemelham em algum ponto. Desse modo, não existiria, por exemplo, apenas uma Oxum, mas várias, sendo que cada "qualidade" remeteria às relações míticas com algum dos outros santos. Desse modo, Oxum Karê, que, segundo meus informantes do Recife, é a qualidade de Oxum que miticamente é esposa de Ogum, é a Oxum mais guerreira. Desse modo, o uso do ter- mo qualidade para designar as várias entidades que incorporam uma "família", remeteria às especificidades de comportamento ou de modo de ser, que cada orixá possui (Rios, 1997). Nesse sentido, esclarece Felipe:

\footnotetext{
Então, meu Logun mesmo que é Ofá-megi. Então, ele não dança muito pra Oxum, ele já vem mais nas terras de Oxossi. Traduzindo a palavra Ofá-megi, fica o "príncipe das terras de Oxossi". Então ele vem muito homem mesmo, ele não vem com muita pinta (trejeito feminino) de... Ele é mais duro pra dançar, eu já vi nas fitas. Aí, muita gente confunde essa qualidade de Logun com Ibualama (qualidade de Oxossi), porque o pé de dança é o mesmo; não tem nada a ver não. (Felipe)
}

Mais que uma categoria mítica, posso dizer que metá-metá fala da possibilidade de maior fluidez na articulação dos atributos de gênero, e é experienciada por todos os deuses. De certa forma, é uma lógica operativa para pensar e constituir as subjetividades que orienta deuses e humanos. Se na sociedade abrangente agenciar alguns dos atributos e características concebidas como integrantes do feminino por pessoas do sexo masculino lançaria a pessoa na esfera dos socialmente desviantes, no caso dos deuses do candomblé, o leque de possibilidades parece ser bem mais diversificado. Vejamos, então, como essa lógica 
medeia o encontro entre o "outro mundo" e o mundo humano.

\section{Deuses e Humanos: Adscrições, Identificações e Posições Identitárias}

Do plano mítico ao mundo humano, um importante momento onde a operação das categorias e lógica de gênero do candomblé se atualiza é o de ser revelado o orixá de cabeça da pessoa. Conforme o pensamento religioso, cada pessoa recebe, na constituição de seu ser, elementos que a relaciona de forma mais profunda com um dos orixás $^{5}$ - água, terra, fogo, folhas, tempestade etc. (cf. Augras, 1983; Barros e Teixeira, 1989). Seriam estes elementos responsáveis pelas diferenças entre os seres humanos, se inscrevendo nos corpos (aspectos fisionômicos, marcas corporais, porte físico), nas moralidades, nos comportamentos e atitudes das pessoas.

Para alguns indivíduos a relação que estabelecem com as divindades é ainda mais visceral: elas têm a possibilidade de emprestar momentaneamente os seus corpos para que estas se manifestem no mundo. Não obstante, é importante frisar que os diversos entes que incorporam os filhos de santo através do transe não são considerados como fazendo parte do eu. Augras (1983), seguindo esta linha de pensamento, cunhou o termo "identidade mítica" para se referir aos processos psicossociais subja- centes à crença de que da filiação humano/orixá os indivíduos herdariam tanto características físicas, quanto de personalidade e de modos de estar-no-mundo. O conceito de identidade mítica proposto por Augras (1983) permite a ponte entre a concepção nativa sobre o si-mesmo, e as identidades que resultam das relações que os sujeitos estabelecem com os seres espirituais.

Nesse contexto de identificações com o "outro mundo", o processo de descoberta do orixá opera em duas vias. Por um lado as características pessoais são avaliadas em busca de uma configuração que aproxime a pessoa de um dos deuses, em uma de suas qualidades; por outro, o modelo oferecido fará com que a pessoa aprimore suas características de modo que, na lida cotidiana no terreiro, mais e mais apresente o esperado para as pessoas que têm a qualidade de seu orixá.

O que deve ser assinalado, entretanto, é que os atributos que são jogados no momento de classificar alguém podem ser partilhados por várias das divindades. Conforme sugeriu Segato (1995), a adscrição dos orixás é parte de um sistema classificatório de base politética. Nesta forma de classificação não é possível fixar um traço indicador universal e alinhar todos os seres em virtude da presença ou ausência deste traço em suas características. 
As classes que obedecem ao princípio politético, como contrário ao monotético, constituem-se de acordo com uma série ou 'cadeia complexa', na qual o atributo definidor muda de um elo para o seguinte: 'não há consistência no tipo das associações, e a variável significativa que faz com que um item seja incluído numa classe, mude para outro sem (...) que exista um 'núcleo da classe'. Isto se dá de forma que não haverá um traço empírico único presente em todos os membros de uma mesma classe, e 'uma classe não poderá mais, portanto, ser definida necessariamente pela presença invariável de certos atributos comuns' (Segato, 1995:177).

Assim, os filhos de um mesmo orixá/classe não exibem, todos, os traços reconhecidos como inerentes ao deus em comum. Ao investigarem-se vários filhos de um determinado orixá, ver-se-á que cada um deles se assemelha a alguns de seus "irmãos de orixá" e ao mesmo tempo se distinguem entre si (Segato, 1995).

Uma primeira característica desse tipo de classificação é que confere aos tipos um aspecto dinâmico, já que são apreendidos a partir de instâncias muito variáveis. De fato, a nossa competência na concepção das classes completa-se constantemente a partir de cada novo espécime que conhecemos, pois em cada instância de adscrição a própria classe (ou idéia do orixá) se refaz. (Segato, 1995:182 )
Esta forma de operar com as classificações terá um importante rebatimento no modo de operar com o sexo e com o desejo sexual das pessoas. Assim, se os atributos pessoais são utilizados para identificar o santo do indivíduo, não são observados os alinhamentos entre sexo do orixá e sexo do filho/a e desejo sexual do orixá e desejo sexual do filho/a. As pessoas podem ser, indistintamente de sexo e orientação sexual, filhos de deuses e deusas, iabás, aborós e metás. Como já mencionei anteriormente, o mais importante na classificação de gênero é a autonomia/dependência (aboró/iabá) e/ou estranheza da configuração formada (metá).

Embora os desejos e as práticas sexuais sejam apreendidas pelo sistema de gênero, são apenas mais alguns atributos, entre outros, a serem operados. Neste sentido, exemplifica Andressa, travesti, mãe de santo, filha de santo aboró, quando questionada sobre a influência do orixá sobre a vida sexual dos seus filhos: "Não, não! Porque se ele influenciasse em alguma coisa, em mim, sobre sexo, eu seria como ele (Xangô), eu gostaria de mulher. Agiria como ele".

É justamente na lógica da metanidade que localizo a importância do sistema de gênero do candomblé para os homens com práticas homossexuais. Ele legitima, mítica e ritualisticamente, as possibilidades de múltiplas articulações entre sexo, orien- 
tação do desejo e gênero. A lógica da metanidade, utilizada indistintamente por todos os deuses, e também a sua atualização concreta, quando uma iabá baixa num homem e/ou um deus incorpora numa mulher, mudando gestualidade e modo de ser, demonstram que os trânsitos de sexogênero são possíveis. Homossexuais e/ou transgêneros encontram, então, respaldo sagrado para suas experiências relacionadas a sexo-gênero-erotismo, em outros contextos consideradas desviantes (Rios, 1997).

Chegando mais perto da questão que me conduz - como os homens com práticas homossexuais articulam em suas narrativas o pensamento religioso sobre sexualidade oferecido pelo candomblé - já é o momento de apresentar mais uma classificação. Esta se configura na interface entre orientação sexual, prazeres corporais e agenciamentos dos atributos aboronidade, metanidade e iabanidade.

\section{Os Homens com Práticas Homossexuais}

No candomblé de nação os homens com práticas homossexuais são pensados a partir de uma classificação que joga com a articulação de dois indicadores: a) A performance pública das pessoas em termos de atributos de gênero - grosso modo, masculinizado e feminilizado; b) As fontes privilegiadas de prazer corporal, grosso modo: pênis e ânus - as interações entre estes dois órgãos são pensadas como atividade (introdução/pênis) e passividade (recepção/ânus).

Na cena pública acredita-se que o primeiro indicador acena para o segundo. Assim, o esperado é que um homem masculinizado, quando na cama com outro homem, sinta prazer na introdução de seu pênis no ânus do outro homem, que, por sua vez deve ser efeminado. Também no nível ideal, essa cartografia de introduções/recepções se espalha por outras partes do corpo (dedo/anus, pênis/boca, língua/anus) e deve continuar obedecendo a dicotomia ativo/masculino e passivo/feminino. Isso significa dizer que, no candomblé, do mesmo modo que nas classes populares brasileiras, as praticas sexuais são generizadas (cf. Fry, 1982; Perlongher, 1987; Parker 1991; Rios, 2004). Há aqui uma nítida relação com a concepção popular brasileira de sexualidade, como identificada por Fry e MacRae (1991):

Podemos dizer que a concepção popular brasileira da sexualidade fala mais de "masculinidade" e "feminilidade", de "atividade" e de "passividade", de "quem está por cima" e de "quem está por baixo" do que sobre a heterossexualidade ou a homossexualidade, que são aspectos que entram no esquema sorrateiramente, por assim dizer. Se este esquema desse importância maior a homossexualidade 
propriamente dita, então o homem que transasse com a bicha certamente teria que ser chamado de homossexual ou algo parecido. Nem sempre isso acontece. (Fry e MacRae, 1991: 50)

Traduzindo o esquema acima para a linguagem do candomblé, entretanto, mais uma vez vemos que a bipolaridade dá passagem para um modelo ternário. Assim, quando escuto os homens sobre as suas vidas sexuais três categorias se configuram: okós, adés e loces.

Os okós são caracterizados como homens ativos (os que penetram). Aboró é o modelo mítico que lhes serve de orientação para gestualidade, atitudes, sotaque e adereços corporais. A virilidade é a marca que faz com que não deixem de ser considerados masculinos ou "homens mesmo", mesmo quando fazem sexo com outros homens. Assim, na categoria okó entrariam tanto homossexuais e bissexuais como heterossexuais, seguindo a classificação das sexualidades própria ao discurso médico, contanto que se apresentem enquanto "homens mesmo", ou seja, não apresentem os "trejeitos efeminados".

Os adés são homens que apresentam traços diacríticos categorizados como femininos, sobretudo no modo de conduzir a gestualidade, o modo de falar e o modo de vestir. Esses traços permitem-lhes explicitar os seus desejos sexuais por ho- mens, ao mesmo tempo em que acenam para a posição de passividade sexual: "Um adé é um homem, que relaciona com outro e tem comportamentos femininos e que é feminino na cama.” (Mário)

$\mathrm{Na}$ categoria loce entrariam homens que no dia a dia passam como sexualmente ativos (okós/aborós), mas que, "entre quatro paredes", podem ser ativos ou passivos na relação sexual: "O loce é como eu tava falando, é aquela coisa: um homem que vai... aquela coisa toda, aí no final ele dá (é penetrado no ânus), ele troca (penetra e é penetrado). Aí é onde tá o loce”. (Cauã)

\section{Embaralhando o Jogo}

Entretanto, os re-arranjos de termos e as significações podem variar. José faz uma distinção entre o okó, o qual caracteriza como o "heterossexual ou bissexual" que se apresente enquanto "homem mesmo" e que seja "ativo" na relação; e o "homossexual ou bissexual" que se apresente enquanto "homem mesmo", mas que exerça também a "parte feminina". Este último ele denominou "okó-metá".

Já na perspectiva de Mário, os okós seriam apenas os "homens heterossexuais": “Um okó, okó mesmo, é o homem que transa com mulher. Que jamais transaria com outro homossexual. Tem uns que até, assim, né?, discrimina". Os homens que têm sexo com homens e mulheres, mesmo 
apresentando-se como machões e ativos na relação, ele os denomina "okó-neca” (onde neca significa pênis), ou "loce", os quais ele caracteriza do seguinte modo:

O bissexual se relaciona com mulheres fazendo heterossexual. Por volta de outros meios, quando tá com outro homem, ele já não tem limites que tem com a mulher. Ele faz uma relação homem e mulher. Entendeu? Com a mulher ele está é ativando uma função homem. E já no caso com o homem, o outro homem, ele vai ativar o seu lado homossexual, quer dizer ativo. Ativando também ser homem; e também ele está ali pra ativar seu lado passivo. Passivo quer dizer o que? O homem que tem o seu lado mulher. O lado que gosta de se sentir... de ser penetrado por outro homem. (Mário)

Embora Mário faça distinção entre okó e okó-neca, e bissexual e homossexual -dizendo que um homem, mesmo que machão e ativo, mas que faça sexo com outro homem, seria homossexual ou bissexual -, em outros trechos de sua fala, aparece uma categoria de homens, "homens mesmo", que embora façam sexo com outros homens não deixam de ser okó:

[No caso você falou do homossexual que só transa com homem, que só transa com homem mesmo]. Com homem! [E esse homem? Ele seria o que?] Ele seria... Olhe, veja só... O homem que se relaciona com o homossexual. Ele é um bissexual, tudo bem que ele está ali fazendo com outro ho... Mas, tem uns homens... Mas, que, se outros homossexuais procuram eles, procuram homens mesmo e chegam até pagar, pagar pra outros homens que possam relacionar com eles. Entendeu? Então, no caso ele tá fazendo, não por gostar de fazer. Está fazendo por ter o como é o nome? - o dinheiro na mão, né? (Mário)

A dispersão de termos e de sentidos notada nos fragmentos de fala de meus informantes diz dos processos concernentes às políticas de identidade, onde classificar o outro, ou a si, acontece sempre contextualmente. Uma mesma pessoa pode ser interpretada de modo diferente a depender de interlocutores, cena e momento. No processo, interesses individuais e/ou coletivos contribuem para a mobilização de agenciamentos das múltiplas categorias disponíveis, onde, muitas vezes, pertencimentos múltiplos são utilizados ao mesmo tempo (Simon e Gagnon, 1999).

A fala de Mário, sobre práticas homossexuais, motivações e identidades, reflete bem isso. Ele, que usa de três modelos (o da biomedicina, o das classes populares e o do candomblé), e que já havia feito elos e correlações entre uns e outros, além de aparentemente ter abandonando a concepção popular que vê o ativo como homem, independentemente de com quem realize o ato sexual, desde que seja o pene- 
trador, em prol de um modelo "modernizado" - o homossexual como homens que fazem sexo com homens independentemente do tipo de prática erótica - volta à classificação popular quando entra em jogo a vontade/motivação/dinheiro. Assim, do mesmo modo que Mário, outros interlocutores usaram, de modo cambiante e a depender das situações, os vários modelos disponíveis. Aliás, fato bastante congruente com a lógica de gênero do candomblé, já apresentada anteriormente.

Como observado nos relatos acima, o jogo de significação a partir das categorias culturalmente oferecidas é bem complexo. Sobretudo quando se ingressa no plano das sínteses contextuais que os atores fazem a partir dos modelos ideais abstrações nativas que tentam orientar, ou são usadas para entender a realidade ( $\mathrm{Si}$ mon e Gagnon, 1999). No momento de minhas interpelações, ao serem confrontados com acontecimentos concretos que desafiam os ideais, os meus interlocutores redescrevem as categorias, guiando-se mais pela lógica que orienta as classificações, do que pelo conteúdo que circunstancialmente lhes preenche.

De outro modo, no momento das entrevistas atualizei os riscos empíricos, eventos que desafiam a ordem cultural (Sahlins, 1990), vividos pelo par masculino-ativo/feminino-passivo, ao ser confrontado com a diversidade de práticas sexuais que podem acontecer entre dois homens. Meus entrevistados e eu nos confrontamos com modalidades daquilo que Fry e MacRae (1991) colocaram como causando escândalo lógico nas categorizações de gênero das classes populares, na medida em que, nas suas representações sóciosexuais, seria esta forma de relação sexual, a relação entre duas pessoas que usam da mesma posição de gênero, a "verdadeira" relação homossexual.

$\mathrm{O}$ acento nas articulações, como em okó-neca e okó-metá, por exemplos, parecem apontar para um espaço vago, constituído pela impossibilidade de significação para determinados acontecimentos pelo par adé-okó. Nesse âmbito, pareceu-me que, mais importante que o modelo categorial empregado, é a idéia de metanidade. A metanidade parece preencher o espaço em aberto (okó-metá), dando passagem para o surgimento da categoria loce.

Não parece, assim, ser por acaso que vem do repertório do orixá Logun Edé o termo utilizado para nomear a categoria emergente. Loce é a própria saudação deste orixá. Aqui se estabelece, mais explicitamente, uma ponte entre a categoria metá e a categoria loce: "Loce é devido o orixá, né? Que isso é a louvação de Logun Edé. Quando se louva Logun Edé se grita assim: Loce loce metá rê-lê! Loce porque ele é dois lados: metade homem, metade mulher". (Felipe) 


\section{Discussão}

\section{Os Prazeres Corporais}

É a multiplicidade de zonas de prazer corporais que parece pedir pela redescrição - pela ampliação do modelo binário. Assim, saindo das performances de gênero e enfocando nos prazeres do baixo corporal, o termo loce é usado para referir-se a "dois homens que fazem sabão"; ou a um ativo que, além de penetrar, goste das carícias e/ou, ainda, que permita que o companheiro passe a mão em suas nádegas, e/ou que se permita "tocar punheta" (masturbação) no outro; ou a um "machudo" (sic.) que na cama com outro ativo "quer comer e ser comido"; ou ainda para dizer sobre um okó, que, ainda que no sexo anal, seja o ativo, nas preliminares orais goste de chupar, e/ou receber a língua do parceiro no ânus.

De certo, o escândalo lógico no caso do candomblé se faz e se resolve na interlocução entre os dois modelos de significar os homens em termos de gênero: o dicotômico das classes populares e o tripartite do candomblé. Para melhor entender a operação dessa interlocução para significar casos concretos, precisamos distinguir pelo menos dois níveis de constituição/apreensão da ação social. No cotidiano não sexual, e para uma pessoa que não domina os códigos desta comunidade se- xual, as performances publicas dos okós ou loces se confundem; ambos são percebidos como "homens mesmo". Eles claramente se diferenciam dos adés/efeminados.

A forma bipolar de roteiro interpessoal funciona no candomblé de nação, mas apenas em alguns momentos e para fins de baixa eroticidade. No decurso ou intervalos entre seqüências rituais, nas fofocas do cotidiano, ou em qualquer momento em que um homem com práticas homossexuais precise pensar sobre as posições sexuais de outro homem, o terno okó-loce-adé volta a vigorar, e os detalhes dos relacionamentos e comportamentos das pessoas são esmiuçados e categorizados.

Várias situações podem colocar em cheque o modelo masculino/feminino de constituir e pensar as parcerias sexuais: um adé que foi pra cama com um okó, e experimentou outras formas de interações sexuais não esperadas pelo script ativo/passivo; o interesse repentino de um okó por um novo membro da comunidade, sobre quem não se sabe a posição na cama e que se mostre também okó na performance pública; parcerias sabidas ou presumidas entre dois okós. Estas e outras situações jogam um homem okó na esfera dos loces.

Muitas vezes estas categorizações interpretam códigos imperceptíveis para os “desavisados". Sobre isso, vale ressaltar que se, para mulheres e homens heterossexuais, o modelo masculino/feminino possa 
fazer inteiro sentido; para os homens com práticas homossexuais é uma categorização que pouco ajuda para a vida prática. Em verdade, o modelo bipolar de gênero fala quase nada do que se passa nas alcovas de pares do mesmo sexo; a bipolaridade parece não dar conta dos gostos e prazeres espalhados pelos corpos. Assim, num circuito social onde desejos e práticas sexuais entre homens estão em constante via de se realizar, um modelo que incorpore explicitamente as hibridizações é bem melhor para pensar.

\section{Considerações Finais}

\section{Vir-a-ser Loce}

Considerando o plano dos deuses, posso dizer que, para além de haver uma oposição entre os atributos das três categorias de gênero - aboró, metá e iabá - e as várias subcategorias (os diversos orixás e qualidades), o que ocorre é um permanente trânsito entre elas. Embora traços sejam marcados como mais próximos de uma ou outra categoria de gênero, são as configurações resultantes das características, os arranjos e re-arranjos que elas formam, mediados por um modo politético de categorizar, que sinalizam os lugares dos entes na classificação de gênero.

De alguma forma o candomblé parece ter se adiantado às ditas sociedades pós-modernas, instituindo, explicitamente, a "ciborguização" (Haraway, 1994) como um modo de operar para constituir posicionamentos identitários. Do plano mítico, das quimeras/orixás, ao mundo ciborgue das pessoas comuns emerge outra categorização de entes. Do diálogo entre as categorizações de gênero dos deuses, a valoração das posições sexuais encenadas entre quatro paredes e outras categorizações disponíveis socialmente (tais como homossexual, heterossexual, bissexual - da ordem médica -, e bicha e homem mesmo, das classes populares) se configuram três classes de homens: okós, adés e loces. Nesse contexto, a lógica da metanidade desestabiliza e rompe com o modelo dicotômico de gênero-sexualidade, próprio às classes populares da sociedade abrangente, enfatizando as hibridizações e trânsitos entre as diferentes possibilidades de articulação entre sexo, gênero, orientação sexual, e fontes privilegiadas de prazer corporal.

Esse sistema possibilita aos homens do candomblé de nação mais recursos para as leituras sobre as posições sócio-sexuais dos seus pares. Afinal, não adianta ser "machão" para ser considerado "homem mesmo". Como nos lembra a guardiã da ordem, a velha Nanã, todo homem têm a possibilidade de ir pra cama com outro homem. Do mesmo modo, a abertura prazerosa dos corpos em interação sexual desloca-os todos para o campo fluido do 
erotismo, que desestabiliza o modelo dicotômico de gênero, no vir-a-ser loce.

\section{Notas}

${ }^{1}$ Denomino religiões africanistas aquelas que se dizem orientar apenas pelas referências africanas para montar tradicionalidades. Assim, temos nesta categoria o xangô e o candomblé, em contraposição à jurema e umbanda, que explicitamente incorporam no fazer religioso, além de elementos referidos como africanos, princípios, crenças e entidades espirituais cristãs e indígenas.

${ }^{2}$ Para tornar o texto mais fluido, reconto os mitos que me foram relatados de forma mais livre, não fazendo menção a quem dos meus interlocutores contou o que. Concebo que os mitos fazem parte da memória coletiva do candomblé, e, portanto, não possuem autoria pessoal. Para um leitor mais curioso sobre como os mitos se expressaram nos relatos pessoais, remeto a Rios (1997).
${ }^{3}$ Vale apontar que esta é a interpretação que os meus informantes ofereceram ao vocábulo. $\mathrm{Na}$ literatura especializada Logun é referido como um derivativo do termo Ologun, feiticeiro. De todo modo, poderíamos aqui trazer a interpretação de Fry (1982) sobre o sucesso das bichas (homens efeminados) enquanto pais de santo. Baseando-se em Victor Turner e Mary Douglas, Fry aponta que figuras ambíguas e liminares são comumente imbuídas de poderes sobrenaturais, sugerindo o fenômeno como um dos fatores que concorrem para a grande presença de homens efeminados como pais de santo.

${ }^{4}$ Haraway (1994) se utiliza da imagem dos ciborgues para fazer uma critica a noção de pureza que sustenta as diferentes formas de opressão, em especial as fundadas no sexo-gênero, no ocidente. A autora aponta que, querendo ou não, na atualidade, todos somos ciborgues: seres impuros que se constituem na hibridização com máquinas, artefatos "artificiais" e seres de outras classes taxonômicas.

5 Sexo entre dois homens, sem penetração anal. Referência às práticas sexuais lésbicas.

\section{Referências}

Augras, M. (1983). O duplo e a metamorfose: a identidade mítica em comu- 
nidades nagô. Petrópolis, RJ: Vozes.

Barros , J.; Teixeira, M. L. (1989). O código do corpo: inscrições do orixás. Em C. Moura. (org.), Meu sinal está em teu corpo. São Paulo, SP: EDICON/EDUSP.

Birman, P. (1995). Fazendo estilo criando gênero. Rio de Janeiro, RJ: Relume Dumará.

Brandão, M. C.; Rios, L. F. (2002). El campo religioso afro-recifense contemporâneo: nuevos modelos religiosos y políticas de identidade. Em J. Monter. (org.), Integración social y cultural. España: Universidade da Corunã.

Fry, P.; Macrae, E. (1991).O que é homossexualidade.São Paulo, SP: Brasiliense.

Fry, P. (1982). Para inglês ver: identidade e política na cultura brasileira. Rio de Janeiro, RJ: Zahar.

Haraway, D. (1994). Um manifesto para o cyborgs: ciência, tecnologia e feminismo socialista na década de 80 . Em H. B. Hollanda. (org.) Tendências e impasses: o feminismo como crítica da cultura. Rio de Janeiro, RJ: Rocco.

Landes, R. (1967). A cidade das mulheres. Rio de Janeiro, RJ: Civilização Brasileira.
Lody, R.; Silva, V. G. (2002). Joãozinho da Goméia: o lúdico e o sagrado na exaltação ao candomblé. Em V. G. Silva. (org.), Caminhos da Alma: memória afro-brasileira. São Paulo: Summus.

Motta, R. (1991). Edjé Balé. Alguns aspectos do sacrifício no xangô de Pernambuco. Tese para o Concurso de Professor Titular, Universidade Federal de Pernambuco, Recife, PE.

Parker, R. (1991). Corpos, prazeres e paixões: a cultura sexual no Brasil contemporâneo. São Paulo, Best Seller.

Perlongher, N. (1987). O negócio do michê: a prostituição viril. São Paulo, SP: Brasiliense.

Prandi, R. (2001). Mitologia dos Orixás. São Paulo, SP: Companhia das Letras.

Ribeiro, R. (1952). Cultos afro-brasileiros do Recife: um estudo de ajustamento social. Recife, PE: Instituto Joaquim Nabuco.

Rios, L. F. (1997). Loce loce, Metá Rê-lê! Homossexualidade e Transe(tividade) de Gênero no Candomblé de Nação. Dissertação de Mestrado. Curso de Pósgraduação em Antropologia, Universidade Federal de Pernambuco, Recife, PE.

Rios, L. F. (2000). A fluxização da um- 
banda carioca e do candomblé baiano em Terras Brasilis e a reconfiguração dos campos afro-religiosos locais. Em Ciudad Virtual de Antropología y Arqueología. Congresso Virtual 2000. http://www.naya.org.ar/congreso20 00/ponencias/Luis_Rios.htm (11/09/2002).

Rios, L. F. (2002). Em busca da tradicionalidade: geração, gênero e sexualidade no candomblé baianocarioca. Sexualidade, Gênero e Sociedade, 8 (17).

Rios, L. F. (2004). O Feitiço de Exu: Um Estudo Comparativo sobre Parcerias e Práticas Homossexuais entre Homens Jovens Candomblesistas e/ou Integrantes da Comunidade Entendida do Rio de Janeiro. Tese de Doutorado. Curso de Pósgraduação em Saúde Coletiva, Universidade do Estado do Rio de Janeiro, Rio de Janeiro, RJ.

Rios, L. F. (No prelo). O paradoxo dos prazeres: trabalho, homossexualidade e estilos de ser homem no candomblé queto fluminense. Etnográfica.

Rubin, G. (1993). O tráfico de mulheres: notas sobre a "economia política" do sexo. Recife, PE: SOS Corpo.
Rubin, G. (1998). Thinking sex: notes for a radical theory of the politics of sexuality”. In: P. Nardir; B. Schneider. (Orgs.), Social perspectives in lesbian and gay studies: a reader. London, UK: Routledge.

Sahlins, M. (1990). Ilhas de História. Rio de Janeiro, RJ: Zahar.

Segato, R. L. (1995). Santos e daimones. Brasília, DF: Editora da UNB.

Simom, W.; Gagnon, J. (1999). Sexual Scripts. Em R. Parker; P. Aggleton. (Orgs.), Culture, society and sexuality: a reader. London, UK: UCL.

Stolcke, V. (2004). La mujer es puro cuento: la cultura del gênero. Estudos Feministas, 12(2): 77-105.

Teixeira, M. L. (1987). Lorogun: identidades sexuais e poder no candomblé. Em C. Moura. (org.), Candomblé, desvendando identidades. Rio de Janeiro, RJ: EMW.

Vance, C. (1989). Social Construction Theory: Problems in the History of Sexuality. Em D. Altman et alii. (Orgs.), Homosexuality, Which Homosexuality? London, UK: Gay Men's.

Vance, C. (1995). A Antropologia redescobre a sexualidade: um comentário teórico. Physis: revista de saúde coletiva, 5(1). 
Weeks, J. (1985). Sexuality and its discontents: meanings, myths, and modern sexualities. London, UK: Routledge and Kegan Paul.

Luis Felipe Rios, Doutor em Saúde Coletiva, Professor do Programa de Pósgraduação em Psicologia e do Programa de Pós Graduação em Antropologia, Universidade Federal de Pernambuco. Endereço: Laboratório de Estudos da Sexualidade Humana - Avenida da Arquitetura, s/n - $\mathrm{CFCH}, 7^{\circ}$. Andar $\mid \mathrm{CEP}$ 50740-550- Recife -PE | Tel.: (81) 2126 8731 Fax: (81) 21268273.

Email: lfelipe.rios@gmail.com 